\title{
The Relationship between Learning Environment and Students Achievement
}

\author{
Afdal $^{1}$, Eka Selvi Handayani ${ }^{2}$, Yoppi Indriani ${ }^{3}$ \\ \{afdalpalalloi@yahoo.com ${ }^{1}$, ekaselvi16@gmail.com², yoppiindriani13@gmail.com ${ }^{3}$ \} \\ 1,2,3 University of Widya Gama Mahakam, Jl. K. H. Wahid Hasyim No. 28 Samarinda, East Borneo
}

\begin{abstract}
This research aims to analyze the relationship between learning environment and students' achievement. This research was conducted in SDN 002 South Bontang, the researchers applied descriptive research. Thus, the data were collected which were; observation, questionnaire, and documentation. Based on the result, the researcher concluded that there was significant correlation between learning environment and students' achievement, especially in SDN 002 South Bontang. In other words, learning environment contributed to support a better students achievement.
\end{abstract}

Keywords: Learning Environment, Students’ Learning Achievement

\section{Introduction}

Education plays a crucial role for countries. In line with this, to improve quality of education it is needed an improvement on the quality of learning process so doses the assessment system. It is interwoven condition in which a great education system results high-quality learning and education that shown in the assessment result[1].

The definition of learning achievement from educator's perspective referring to Regulation of National Education Minister Number 104 year 2005 is a process of collecting information or evidence about student's learning outcome including their competence in spiritual and social attitude, knowledge, and skill, which is conducted as planned and systematically, during and after the learning process[2].

Learning outcome is an evaluation act that reveals aspect of thinking process (cognitive domain) and other psychological aspects such as value and attitude (affective domain) and psychomotor domain that attached to student's individual[3]. It can be said that learning result can be disclosed holistically through the description of student's achievement at the end of learning process [4].

According to [5], [6], environment involves all condition in the world that in particular way influences our behavior, growth, development, or life process, excluding the genes. Even, the genes are considered preparing environment for other genes [7]. In addition, Wiyono (2003: 29) defines learning outcomes as a condition and all facilities that used for everyday learning activity. Ali (2007: 143) added that a supporting learning environment must be capable to grow and develop good and productive learning. The encouraging learning environment includes physical, social and psychological environment[8]. So that, students are low-motivated since their parents do not encourage them. Student's financial condition makes students do not have proper learning equipment such as stationary, books and others[9]. Referring to the issue above, 
the researchers are interested to investigate "correlation between learning environment and student's learning achievement".

\section{Method}

This is a structured research, started from hypothesis testing, choosing research method, arranging instrument, collecting data, analyzing data, and drawing conclusion from the conducted research. a correlation research is applied to find out the relationship of independent variable; school environment $(\mathrm{X})$ in dependent reliable; student's learning achievement $(\mathrm{Y})$.

The population of this research is all students of SDN 002 South Bontang, consisting of 600 students from four classes of first grade and fifth grade, three classes from second, third, fourth, and sixth grade. From the population, 90 students were taken as the research sample.

This study was conducted in SDN 002 South Bontang, East Borneo, Indonesia. The researcher carried out the investigation on April 2018. The research instruments are in form of learning achievement variable (Y), learning environment $(\mathrm{X})$ and research instrument testing. In collecting the data, the researcher employed close-ended questionnaire since the answers are provided so the respondents enable to choose the given answer. The questionnaire used Likert scale to measure learning environment and learning outcome. Besides that, the researchers also used document for collecting data as real data, such as data of student, school profile and photos.

\section{Result and Discussion}

The questionnaire was distributed to 90 students to measure students' capability to reach learning objectives. The questionnaire consists of eight items with Likert scale one to five. Moreover, the data were descriptively analyzed through SPSS 16.0 for windows, that the result is described in the table 1 .

Table 1. Data of Descriptive Statistic of Learning Achievement in SDN 002 Cluster VI South Bontang

\begin{tabular}{l|l}
\hline Descriptive Statistics & Learning Achievement \\
\hline Valid & 90 \\
Missing & 0 \\
Mean & 32.78 \\
Median & 33.00 \\
Mode & 32 \\
Std. Deviation & 3.906 \\
Variance & 88.097 \\
Range & 14 \\
Minimum & 26 \\
Maximum & 40 \\
Sum & 2950 \\
\hline
\end{tabular}

It is clearly seen that there were 90 data collected and none is missing. From the table above, it can be seen that the score interval of learning achievement is 14 , with the lowest score 26 and the highest score 40. If the average score, 32.78, compared with the ideal average score, 26 , then it can be said that student's learning achievement is above ideal average score. In other words, 
students' learning achievement in SDN 002 Cluster IV South Bontang is considered good. The average score is 32.78 almost similar to median score, 33.00. It shows that most of students reached almost balance score since it is in between upper and lower score. Meanwhile, the mode score is 33, meaning that at normal distribution the subjects choose or gain score 33 .

Furthermore, to find out the category of learning achievement score can be seen in data distribution of learning achievement $(\mathrm{Y})$ in the table 2.

Table 2. Frequency Distribution of Students' Learning Achievement Score

\begin{tabular}{|c|c|c|c|c|}
\hline \multicolumn{3}{|c|}{ Interval } & \multirow{2}{*}{$\begin{array}{l}\text { Absolute Frequency } \\
15\end{array}$} & \multirow{2}{*}{$\begin{array}{l}\text { RelativeFrequency } \\
16.67\end{array}$} \\
\hline 26 & - & 28 & & \\
\hline 28 & - & 30 & 14 & 15.56 \\
\hline 30 & - & 32 & 14 & 15.56 \\
\hline 32 & - & 34 & 16 & 17.78 \\
\hline 34 & - & 36 & 12 & 13.33 \\
\hline 36 & - & 38 & 12 & 13.33 \\
\hline & - & 40 & 7 & 7.78 \\
\hline \multicolumn{3}{|c|}{ TOTAL } & 90 & 100 \\
\hline
\end{tabular}

The table above shows category of student's learning achievement, consisting of three categories; good, fair and low. The good category is the average score added one standard deviation (SD). The low category is the average score reduced one's standard deviation. Meanwhile, the medium category is score between good and low category.

Based on the descriptive analysis, the mean score is 32.78 with standard deviation (SD) 3.906. The good category is when $32.78+3.906=36.686$ rounded into 37 . The low category is when $32.78-3.906=28.874$ rounded into 29. Meanwhile, the medium category is between 38 and 28 . For further explanation, the following table will display the data;

Table 3. Category of Learning Achievement

\begin{tabular}{ccccc}
\hline No & Category & Score & Frequency & Percentage \\
\hline 1 & Low & $\leq 29$ & 20 & $22 \%$ \\
2 & Medium & $30-36$ & 51 & $57 \%$ \\
3 & Good & $\geq 37$ & 19 & $21 \%$ \\
& TOTAL & & 90 & $100 \%$ \\
\hline
\end{tabular}

From the table above, it is seen that $22 \%$ (20) students fall to low category, $57 \%$ (51) students are in medium category, and $21 \%$ (19) students are in good category. In conclusion, students in SDN 002 Cluster VI South Bontang are mostly in medium category and the rests are in low and good category. The following pie chart will display the result; 


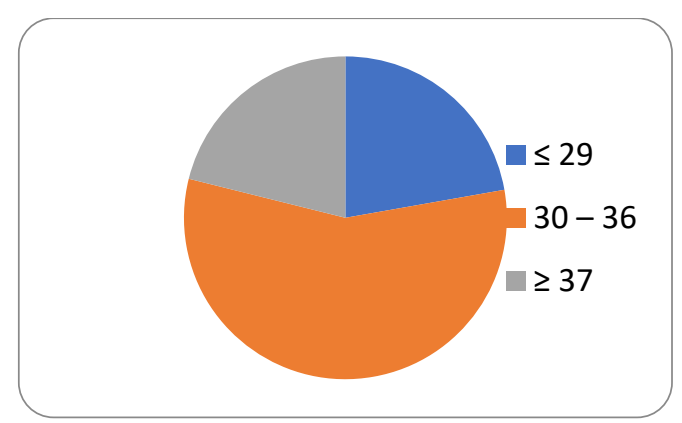

Figure 1

The result of questionnaire was analyzed with SPSS 16.0 that displayed in the following table;

Table 5. Data of Descriptive Statistics of Learning Environment in SDN 002 Cluster VI South Bontang

\begin{tabular}{l|l}
\hline Descriptive Statistics & Learning Achievement \\
\hline Valid & 90 \\
Missing & 0 \\
Mean & 39.53 \\
Median & 40.00 \\
Mode & 40 \\
Std. Deviation & 3.058 \\
Variance & 9.353 \\
Range & 16 \\
Minimum & 30 \\
Maximum & 46 \\
Sum & 3558 \\
\hline
\end{tabular}

There are 90 data were collected and none were missing. The interval of data is 16 , from the lowest score 30 and the highest score 46. Based on central tendency, the mean score is 39.53 , compared with ideal average score, 30 , it can be said the learning environment is above ideal average score. In brief, the learning environment in SDN 002 Cluster IV South Bontang is considered good, with average score 39.53, that almost reach median score 40.00. It shows that student's score for learning environment is almost balance since it is in between of upper and lower score of average score.Moreover, the following table display category of learning environment;

Table 6. Frequency Distribution of Learning Environment

\begin{tabular}{ccc|c|c}
\hline \multicolumn{2}{l|}{ Interval } & & Absolute Frequency & Relative Frequency \\
\hline 32 & - & 34 & 4 & 4.44 \\
34 & - & 36 & 11 & 12.22 \\
36 & - & 38 & 14 & 15.56 \\
38 & - & 40 & 27 & 30.00 \\
40 & - & 42 & 22 & 24.44 \\
42 & - & 44 & 9 & 10.00 \\
44 & - & 46 & 3 & 3.33 \\
\multicolumn{2}{l}{ TOTAL } & 90 & 100 \\
\hline
\end{tabular}


From the frequency distribution, there are three categories; good, medium and low learning environment category. The good category is the average score added one standard deviation. The low category is the average score reduced one standard deviation. The medium category is score between good and low category.

Based on the descriptive analysis result, it is gained mean score $=39.35$, added with one standard deviation $=3.058$, resulting 42.588 rounded into 42 , categorized as good category. For low category, the mean score $=39.53$ is reduced with one standard deviation $=3.058$, resulting 36.472 rounded off into 36. Moreover, the score for medium category is between 37 and 41 . The following table will show the result;

Table 3. Category of Learning Achievement

\begin{tabular}{lllll}
\hline No & Category & Score & Frequency & Percentage \\
\hline 1 & Low & $\leq 36$ & 15 & $17 \%$ \\
2 & Medium & $37-41$ & 51 & $57 \%$ \\
3 & Good & $\geq 42$ & 24 & $26 \%$ \\
TOTAL & & 90 & $100 \%$ \\
\hline
\end{tabular}

From the table above, it can be seen that 15 students $(17 \%)$ reached low category for learning environment. 51 students $(57 \%)$ are in medium category. 24 students $(26 \%)$ are in low category. In general, students' learning environment is mostly in medium category, as displayed in the following pie chart.

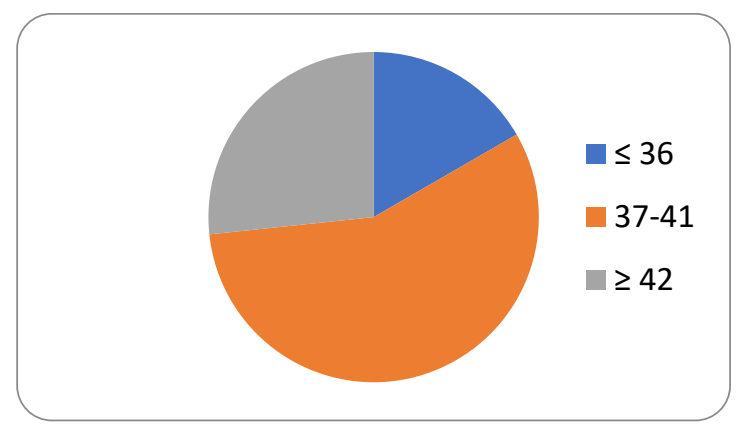

The result of normality calculation gains significant score 0.304 , at significant rate $\alpha=0.05$. The criteria for normal distribution are significant value $>$ significant rate; $\alpha$. Since the significant value $>\alpha=0.05$, then it can be said that Ha is accepted, meaning that the research variable has normal distribution. The hypothesis proposed in this study were; 1) Alternative hypothesis (Ha); "there is significant correlation between learning environment (X) and student's learning achievement (Y) at SDN 002 ClusterVI south Bontang Selatan academic year 
2017/2018"; 2) Null hypothesis (Ha); "there is no significant correlation between learning environment $(\mathrm{X})$ and student's learning achievement (Y) at SDN 002 ClusterVI south Bontang Selatan academic year 2017/2018".

The simple analysis on correlation computation between variable learning environment $(\mathrm{X})$ and learning achievement (Y) that can be seen in table 4.7., results significant value $0.000<$ 0.05. Consequently, the null hypothesis is rejected. It can be said that there is significant relationship between learning environment and student's learning achievement at SDN 002 Cluster VI South Bontang academic year 2017/2018. In conclusion, the better the learning achievement is, the better student's learning achievement.

\section{Correlations}

\begin{tabular}{|r|r|}
\hline \multicolumn{1}{|l|}{$\begin{array}{l}\text { Learning } \\
\text { Atmosphere }\end{array}$} & Result \\
\hline 1 & $448 * *$ \\
& .000 \\
90 & 90 \\
\hline $448 * *$ & 1 \\
.000 & \\
90 & 90 \\
\hline
\end{tabular}

**. Correlation is significant at the 0.01 level (2-tailed).

Result of hypothesis testing shows that there is positive significant relationship between learning environment and learning achievement. In other words, good learning environment results good learning achievement and vice versa. Learning environment as the main component for supporting student's learning achievement is clearly connected. The research result also reveals that factor of environment such as facilities, surrounding environment, parents' attention and people around students significantly contribute to student's learning result.

Referring to previous research conducted by Winarno (2012), investigating the influence of learning environment and achievement motivation toward learning achievement at industrial automation engineering competence at Vocational School 2 Depok Yogyakarta, he found that learning achievement is the result of learning process that is influenced by student's habit, motivation and individual reason. Student's habit is also affected by learning achievement that supports good quality of student's habit. Great motivation in reaching achievement is reinforced by many aspects that encourage students to do efforts achieving good result. Learning achievement is also influenced by learning environment and motivation from each student to reach the achievement.

Similarly, this study investigated the role of learning environment on learning achievement. However, this study only focuses on the relationship between the two variables. Wiyono (2003: 29) emphasized that learning environment is all facilities that used for learning in daily life. Learning environment is shaped through some influential factors. The learning achievement also becomes learning source and learning aids [10].

Learning environment includes social and non-social environment. Social environment is student's interaction with family, friends, teachers and classmates. Non-social environment 
refers to physical entity, such as a place to study, learning atmosphere, and learning aids at school (Aristyani, 2015).

Learning environment or commonly called education environment is a place where the learning process carried out, influenced by external factors toward the activity sustainability [12]. The explanation above has shown clearly shown that learning achievement relates significantly to student's learning achievement. Satisfying learning result that suitable with the learning objectives can be achieved when student learn and do the learning process in great and supporting learning environment.

\section{Conclusion}

Based on the data analysis and the research result above, it can be concluded that learning environment correlates to student's learning achievement. Meaning that, good learning environment will result better learning achievement. However, poor learning environment makes worse learning achievement.

\section{References}

[1] N. E. El-Attar, N. A. El-Ela, and W. A. Awad, "Integrated learning approaches based on cloud computing for personalizing e-learning environment," Int. J. Web-Based Learn. Teach. Technol., vol. 14, no. 2, pp. 67-87, 2019.

[2] K. Botsoglou, E. Beazidou, E. Kougioumtzidou, and M. Vlachou, "Listening to children: using the ECERS-R and Mosaic approach to improve learning environments: a case study," Early Child Dev. Care, vol. 189, no. 4, pp. 635-649, 2019.

[3] F. Harahap, N. E. A. Nasution, and B. Manurung, "The effect of blended learning on student's learning achievement and science process skills in plant tissue culture course," Int. J. Instr., vol. 12, no. 1, pp. 521-538, 2019.

[4] C. Yao, "An investigation of adult learners' viewpoints to a blended learning environment in promoting sustainable development in China," J. Clean. Prod., vol. 220, pp. 134-143, 2019.

[5] J. M. Mortimore and R. L. Baker, "Supporting Student-Led Content Creation in the Distance Learning Environment with LibGuides CMS," J. Libr. Inf. Serv. Distance Learn., vol. 13, no. 1-2, pp. 88-103, 2019.

[6] C.-W. Liao, C.-H. Chen, and S.-J. Shih, "The interactivity of video and collaboration for learning achievement, intrinsic motivation, cognitive load, and behavior patterns in a digital game-based learning environment," Comput. Educ., vol. 133, pp. 43-55, 2019.

[7] Ramayulis, Dasar-Dasar Kependidikan Suatu Pengantar Ilmu Pendidikan. Jakarta: Kalam Mulia, 2015.

[8] M. Oketch, "Access, poverty and learning achievement for primary school leavers in Kenya: analysis of evidence from 47 counties," Compare, vol. 49, no. 1, pp. 1-15, 2019.

[9] B. Bai, G. C. N. Chao, and C. Wang, "The Relationship between Social Support, SelfEfficacy, and English Language Learning Achievement in Hong Kong," TESOL Q., vol. 53, no. 1, pp. 208-221, 2019.

[10] B. Winarno, "Pengaruh Lingkungan Belajar Dan Motivasi Berprestasi Terhadap Hasil Belajar Siswa Kompetensi Keahlian Teknik Otomasi Industri Di Sekolah Menengah Kejuruan Negeri 2 Depok Yogyakarta," Fak. Tek. Univ. Negeri Yogyakarta Skripsi, 2012. 
[11] noni suci aristyani, "Pengaruh kondisi siswa dan lingkungan belajar terhadap motivasi belajar siswa kelas XI kompetensi keahlian administrasi perkantoran di smk muhamadiyah 1 tempel," 2015.

[12] A. Widyaningtyas, Sukarmin, and Y. Radiyono, "PERAN LINGKUNGAN BELAJAR DAN KESIAPAN BELAJAR TERHADAP PRESTASI BELAJAR FISIKA SISWA KELAS X SEKOLAH MENENGAH ATAS NEGERI 1 PATI,"Pendidik. Fis., 2013. 